\title{
Accuracy analysis of automatic distortion correction
}

\author{
Jakub Kolecki, Antoni Rzonca \\ ${ }^{1}$ AGH University of Science and Technology \\ Faculty of Mining Surveying and Environmental Engineering \\ Department of Geoinformation, Photogrammetry and Remote Sensing of Environment \\ 30 Mickiewicza Av., 30-059 Cracow, Poland \\ email: kolecki@agh.edu.pl; arz@agh.edu.pl
}

Received: 09 September 2014 / Accepted: 21 April 2015

\begin{abstract}
The paper addresses the problem of the automatic distortion removal from images acquired with non-metric SLR camera equipped with prime lenses. From the photogrammetric point of view the following question arises: is the accuracy of distortion control data provided by the manufacturer for a certain lens model (not item) sufficient in order to achieve demanded accuracy? In order to obtain the reliable answer to the aforementioned problem the two kinds of tests were carried out for three lens models.

Firstly the multi-variant camera calibration was conducted using the software providing full accuracy analysis. Secondly the accuracy analysis using check points took place. The check points were measured in the images resampled based on estimated distortion model or in distortion-free images simply acquired in the automatic distortion removal mode.

The extensive conclusions regarding application of each calibration approach in practice are given. Finally the rules of applying automatic distortion removal in photogrammetric measurements are suggested.
\end{abstract}

Keywords: camera calibration, radial distortion, distortion correction, accuracy analysis, bundle adjustment

\section{Introduction}

If non-metric cameras are going to be applied in measurements, they basically have to be calibrated prior to the image acquisition. This increases costs and takes additional time. Besides an appropriate test-field is needed. If only the metric information is going to be extracted, the calibration must be carried out both for visible range sensors (Tokarczyk and Boroń, 2000; Tokarczyk et al., 2007), and for thermal sensors as well (Wróbel et al., 2011). As the automatic reduction of distortion seems to be very attractive way to avoid often inconvenient test-field calibration, the authors aimed to verify its potential in the aspect of close-range accuracy demands. Final conclusions will be given after two-step accuracy analysis. 
In the first step for each lens $(20 \mathrm{~mm}, 28 \mathrm{~mm}, 35 \mathrm{~mm})$ the accuracy of calibration in three variants will be evaluated:

- Using the images acquired with automatic reduction of distortion (ARD) turned off, with the estimation of internal orientation parameters (IOPs) and distortion model parameters (DMPs).

- Using the images acquired with automatic reduction of distortion, with estimation of IOPs and DMPs.

- Using the images captured with ARD and with estimation of IOPs only.

In the second step, the analysis involves check point measurements using distortion free images and parameters obtained as results of the camera calibration obtained in three aforementioned variants.

As a result the impact of ARD on check point accuracy will be given. The comparison between accuracy achieved using traditional calibration and ARD will be provided.

\section{Theoretical background}

\subsection{Automatic distortion reduction (ARD)}

Each lens incorporates some systematic errors to acquired images: photogrammetric lenses slight, consumer-grade lenses large. Taking the demanded accuracy of imagebased 3D point measurement into account, an accurate information about the fiducial components of this errors is necessary. Many different approaches were described in recent time (Clarke and Fryer, 2003; Hamid and Ahmad, 2014). The present papers address specific, innovative solutions of the problem (Grammaticopoulos et al., 2006; Ricolfe and Sanches, 2009). Using popular cameras (e.g. SLR) as the semi metric sensors involve the necessity of determination of both radial and tangential distortion in addition to IOPs. Laboratory (usually test-field) camera calibration is a standard procedure to determine all of these coefficients. Estimated coefficients are subsequently used during the photogrammetric workflow, typically using one of the following approaches.

First and the trivial way is to determine the IOPs and coefficients of the distortion polynomial model (ISPRS model, USGS model, Brown model (Brown, 1971)) and afterwards resample the distorted photographs to distortion free form using a provided computer program. In practice some remaining distortion is always present despite the performed resampling, but its influence on the accuracy of final products is negligible, provided the calibration was carried out properly.

The second, very common approach is to use DMPs to calculate corrections to measured image coordinates in the distorted images, each time they are used in processing. In this case no resampling is needed.

Another approach involves on-the-fly processing of the distorted images and calibration data, during all the calculations and during the process of image displaying 
in the photogrammetric work station (Melo et al., 2012; Van der Jeught et al., 2013). The coefficients of distortion model are stored in the photogrammetric project. Such approach is very efficient during standard calculations (like relative orientation, absolute orientation, aerial triangulation). On the other hand some difficulties may arise while displaying the undistorted data because of limited performance of graphical processing unit.

The last, quite new approach involves automatic reduction of distortion (ARD) directly by the camera software, right before storing the image in the flash memory. However it has to be mentioned that such solution is dedicated mostly to photographers not for photogrammetric engineers. A manufacturer provides the distortion control data for each lens model, without information of its accuracy and reliability. Besides the distortion may vary among all lens copies of the same model. It is not determined for a certain camera-lens set. Besides once given DMPs and IOPs may not stay constant in time. Evaluation of the accuracy potential of automatic distortion reduction is an important and interesting research field.

The first (the traditional one) approach will be used as a reference with respect to the last method during the following discussion.

\subsection{Calibration approach}

Camera calibration can be solved using the bundle adjustment procedure involving estimation of IOPs and DMPs as parameters. The basic assumption of bundle adjustment involves minimization of squares of image coordinate residuals, finding the most probable parameters of a functional model. In the first step the control and tie point coordinates are measured in the acquired images. Then the calibration is calculated. Plots showing the influence of radial distortion on the image coordinates can be generated. The accuracy analysis basically involves checking RMSEs of image coordinates and the standard deviations of model parameters.

\subsection{Evaluation of the automatic distortion reduction}

Calibrating the camera one may conduct the accuracy analysis of automatic distortion removal performed by digital camera software. Two sets of images have to be acquired: one without $\mathrm{ARD}$ and the second using it. Then the calibration procedure in the 3 variants follows.

In the first variant the full calibration (IOPs + DMPs) is carried out using images acquired with ARD. It will be treated as a reference variant both in the practical (that's the way the calibration is currently done) and analytical sense - obtained parameters will be treated as the reference values for two other variants.

The second variant involves using images captured with ARD and the subsequent camera calibration just in the same way as in the first variant. As a result of ARD not 
only the DMPs but also the IOPs are supposed to have different values as in the first variant. Calibration results are going to show how big is distortion despite applying ARD.

The third variant also involves using the ARD images, however within the calibration only the IOPs will be estimated. This variant enables evaluation of remaining distortion influence on the accuracy of photogrammetric measurements.

\subsection{Accuracy analysis of photogrammetric measurements}

Besides analyzing the accuracy in three above mentioned variants, further accuracy analysis was performed involving comparison of check point coordinates. Appropriate measurements were carried out in the images that were not used for calibration. Two input sets (automatically undistorted and affected with distortion) of stereo photographs with 20 check points (ChPs) and 4 control points (CPs) were used. CPs were used for image orientation using resection. The control measurement was carried out in three basic variants (Table 1). Additional "zero variant" (first row) was added to show the overall distortion influence. In each variant measured and reference ChPs' coordinatates were compared. Coordinates of ChPs were determined using photogrammetric intersection.

Table 1. Variants of stereophotogrammetric control measurements

\begin{tabular}{|c|c|c|c|c|}
\hline $\begin{array}{c}\text { Control } \\
\text { variant no. }\end{array}$ & ARD & $\begin{array}{c}\text { Distortion } \\
\text { correction } \\
\text { (resampling) }\end{array}$ & $\begin{array}{c}\text { Parameters used } \\
\text { for distortion } \\
\text { correction }\end{array}$ & IOPs \\
\hline 0 & NO (set \#1) & NO & - & $\begin{array}{c}\text { default: } P P A C x=P P A C y=0, \\
c k=\text { focal length }\end{array}$ \\
\hline 1 & NO (set \#1) & YES & $\begin{array}{c}\text { results of } \\
\text { calibration in } \\
\text { variant } 1\end{array}$ & $\begin{array}{c}P P A C x=P P A C y=0, \\
c k \text { obtained in calibration } \\
\text { variant no. } 1\end{array}$ \\
\hline 2 & YES (set \#2) & YES & $\begin{array}{c}\text { results of } \\
\text { calibration in } \\
\text { variant } 2\end{array}$ & $\begin{array}{c}P P A C x=P P A C y=0, \\
c k \text { obtained in calibration } \\
\text { variant no. 2 }\end{array}$ \\
\hline 3 & YES (set \#2) & NO & - & $\begin{array}{c}P P A C x=P P A C y=0, \\
\text { obtained in calibration } \\
\text { variant no. 1 }\end{array}$ \\
\hline
\end{tabular}




\section{Measurements, calculations and results}

\subsection{Data acquisition: camera, lenses, test-field and camera stations}

The tests were carried out using, Nikon D800 SLR small-format camera (http:// www.nikon.pl/pl_PL/product/digital-cameras/slr/professional/d800). The physical sensor dimensions are $24 \mathrm{~mm} \times 35.9 \mathrm{~mm}$, providing the $7360 \times 4912$ pix. resolution. Following lenses were tested: Nikon Nikkor $20 \mathrm{~mm}$ f/2.8d, Nikon Nikkor AF-S $28 \mathrm{~mm} \mathrm{f} / 1.8 \mathrm{~d}$ and Nikon Nikkor AF-S $35 \mathrm{~mm}$ f/1.4d. The access to the camera was provided by Terramap Ltd. from Cracow.

All the images were acquired in the test field located at the Department of Geoinformation, Photogrammetry and Remote Sensing of Environment at the AGH University of Science and Technology. The test field is fitted with approximately 150 points. Some of them were treated as tie points due to some mechanical failure of targets, that may result in accuracy drop of conducted calibrations.

The 11 images were captured both with automatic distortion reduction turned on and turned off. The most important rule during the image acquisition was to fill all the image area with control points to ensure appropriate distortion estimation. The first image was taken in front of the test field. Then the 4 images followed: from the left, right, top and bottom. Subsequently 4 corner images were taken. Besides, the stereo pair was acquired for the accuracy analysis purposes. The aperture pre-selection option was chosen during acquisition. The larger values of aperture were preferred to ensure better depth of field. The camera with each lens was focused at the average distance of the acquisition. The $0.3 \mathrm{~mm}$ sampling distance in the object space was provided.

\subsection{Camera calibration in 3 scenarios and the control calibration}

Photogrammetric measurements of $\mathrm{ChP}$ and $\mathrm{CP}$ were carried out automatically in Testfield Measurement Toolbox (Kolecki et al, 2007). Calculations were conducted in Camera Calibrator software, designed by Ing. Władysław Mierzwa in 2009. The calibration is calculated using self-calibration algorithm, allowing inclusion of tie points, parameter fixation and accuracy analysis. Basically the software uses the USGS distortion model, however with the aim of possible comparison with results of other software the more popular Brown model (Brown, 1971) was used. After caring out the measurements in all sets of images, the following calculations were performed (see the chapter 2.3). 
3.2.1. Calibration using images without $A R D$ - variant 1

Table 2. Results of camera calibration in variant \#1

\begin{tabular}{|l|c|c|c|c|c|c|}
\hline \multirow{2}{*}{ Parameter } & \multicolumn{2}{|c|}{$20 \mathrm{~mm}$ lens } & \multicolumn{2}{c|}{$28 \mathrm{~mm}$ lens } & \multicolumn{2}{c|}{$35 \mathrm{~mm}$ lens } \\
\cline { 2 - 7 } & Value & $\begin{array}{c}\text { Std. } \\
\text { deviation }\end{array}$ & Value & $\begin{array}{c}\text { Std. } \\
\text { deviation }\end{array}$ & Value & $\begin{array}{c}\text { Std. } \\
\text { deviation }\end{array}$ \\
\hline$P P A C x[\mathrm{~mm}]$ & -0.0670 & 0.0014 & -0.1559 & 0.0023 & -0.0351 & 0.0035 \\
\hline$P P A C y[\mathrm{~mm}]$ & 0.1996 & 0.0012 & 0.2118 & 0.0018 & 0.2355 & 0.0026 \\
\hline $\begin{array}{l}\text { Principal } \\
\text { distance } \\
{[\mathrm{mm}]}\end{array}$ & 20.4197 & 0.0017 & 28.7991 & 0.0020 & 36.1231 & 0.0030 \\
\hline$K 1\left[\mathrm{~mm}^{-2}\right]$ & $-2.889 \mathrm{E}-004$ & $9.148 \mathrm{E}-007$ & $-1.058 \mathrm{E}-004$ & $6.648 \mathrm{E}-007$ & $-8.903 \mathrm{E}-005$ & $6.218 \mathrm{E}-007$ \\
\hline$K 2\left[\mathrm{~mm}^{-4}\right]$ & $5.669 \mathrm{E}-007$ & $4.856 \mathrm{E}-009$ & $1.311 \mathrm{E}-007$ & $3.321 \mathrm{E}-009$ & $5.938 \mathrm{E}-008$ & $3.124 \mathrm{E}-009$ \\
\hline$K 3\left[\mathrm{~mm}^{-6}\right]$ & $-1.440 \mathrm{E}-010$ & $7.805 \mathrm{E}-012$ & $-3.373 \mathrm{E}-011$ & $4.980 \mathrm{E}-012$ & $3.241 \mathrm{E}-011$ & $4.714 \mathrm{E}-012$ \\
\hline$P 1\left[\mathrm{~mm}^{-2}\right]$ & $-1.027 \mathrm{E}-005$ & $1.398 \mathrm{E}-006$ & $1.713 \mathrm{E}-005$ & $1.082 \mathrm{E}-006$ & $8.112 \mathrm{E}-006$ & $9.964 \mathrm{E}-007$ \\
\hline$P 2\left[\mathrm{~mm}^{-2}\right]$ & $2.966 \mathrm{E}-006$ & $1.013 \mathrm{E}-006$ & $-4.248 \mathrm{E}-007$ & $7.675 \mathrm{E}-007$ & $6.878 \mathrm{E}-006$ & $6.927 \mathrm{E}-007$ \\
\hline RMSE $[\mathrm{px}]$ & 0.6903 & & 0.5837 & & 0.3961 & \\
\hline
\end{tabular}

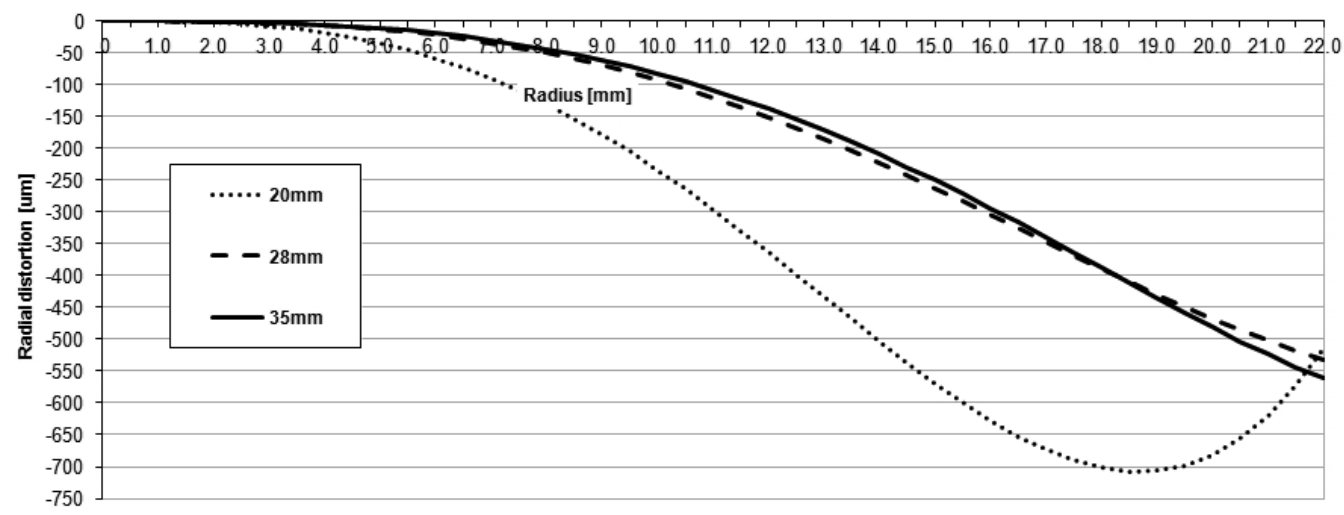

Fig. 1. Radial distortion curves as a result of camera calibration in variant \#1

In this variant the measurements carried out in images without ARD were utilized for each lens $(20,28$ and $35 \mathrm{~mm})$. The IOPs and DMPs were estimated. The results and the accuracy parameters are given in Table 2. Distortion profiles are shown in the figure 1. Curves representing distortion for $28 \mathrm{~mm}$ and $35 \mathrm{~mm}$ lenses nearly coincide. The $20 \mathrm{~mm}$ lens incorporates higher distortion values within almost the whole frame and its distortion curve reaches extreme in 18.5 radius. Tangential distortion parameters seem not to differ a lot. 
Table 3. Results of camera calibration in variant \#2

\begin{tabular}{|l|c|c|c|c|c|c|}
\hline \multirow{2}{*}{ Parameter } & \multicolumn{2}{|c|}{$20 \mathrm{~mm}$ lens } & \multicolumn{2}{c|}{$28 \mathrm{~mm}$ lens } & \multicolumn{2}{c|}{$35 \mathrm{~mm}$ lens } \\
\cline { 2 - 7 } & Value & $\begin{array}{c}\text { Std. } \\
\text { deviation }\end{array}$ & Value & $\begin{array}{c}\text { Std. } \\
\text { deviation }\end{array}$ & Value & $\begin{array}{c}\text { Std. } \\
\text { deviation }\end{array}$ \\
\hline$P P A C x[\mathrm{~mm}]$ & -0.0586 & 0.0016 & -0.1609 & 0.0026 & -0.0296 & 0.0032 \\
\hline$P P A C y[\mathrm{~mm}]$ & 0.1921 & 0.0015 & 0.2119 & 0.0020 & 0.2408 & 0.0024 \\
\hline $\begin{array}{l}\text { Principal } \\
\text { distance } \\
{[\mathrm{mm}]}\end{array}$ & 19.8920 & 0.0019 & 28.4035 & 0.0020 & 35.7177 & 0.0028 \\
\hline$K 1\left[\mathrm{~mm}^{-2}\right]$ & $-1.369 \mathrm{E}-005$ & $1.038 \mathrm{E}-006$ & $4.231 \mathrm{E}-006$ & $7.002 \mathrm{E}-007$ & $-1.398 \mathrm{E}-006$ & $5.601 \mathrm{E}-007$ \\
\hline$K 2\left[\mathrm{~mm}^{-4}\right]$ & $6.811 \mathrm{E}-008$ & $5.407 \mathrm{E}-009$ & $-1.780 \mathrm{E}-008$ & $3.427 \mathrm{E}-009$ & $7.743 \mathrm{E}-009$ & $2.738 \mathrm{E}-009$ \\
\hline$K 3\left[\mathrm{~mm}^{-6}\right]$ & $-1.109 \mathrm{E}-010$ & $8.409 \mathrm{E}-012$ & $2.169 \mathrm{E}-011$ & $5.021 \mathrm{E}-012$ & $-1.141 \mathrm{E}-011$ & $4.011 \mathrm{E}-012$ \\
\hline$P 1\left[\mathrm{~mm}^{-2}\right]$ & $-1.066 \mathrm{E}-005$ & $1.591 \mathrm{E}-006$ & $8.249 \mathrm{E}-006$ & $1.187 \mathrm{E}-006$ & $1.951 \mathrm{E}-006$ & $9.001 \mathrm{E}-007$ \\
\hline$P 2\left[\mathrm{~mm}^{-2}\right]$ & $1.650 \mathrm{E}-005$ & $1.206 \mathrm{E}-006$ & $1.316 \mathrm{E}-005$ & $8.339 \mathrm{E}-007$ & $1.294 \mathrm{E}-005$ & $6.365 \mathrm{E}-007$ \\
\hline RMSE $[\mathrm{px}]$ & 0.8267 & & 0.6481 & & 0.3724 & \\
\hline
\end{tabular}

\subsubsection{Calibration using images with ARD - variant 2}

The second calibration was calculated for all lenses using images with ARD turned on. The results and the accuracy parameters are given in table 3 . The $20 \mathrm{~mm}$ lens incorporates highest distortion values. Figure 2 shows distortion curves for all 3 lenses.

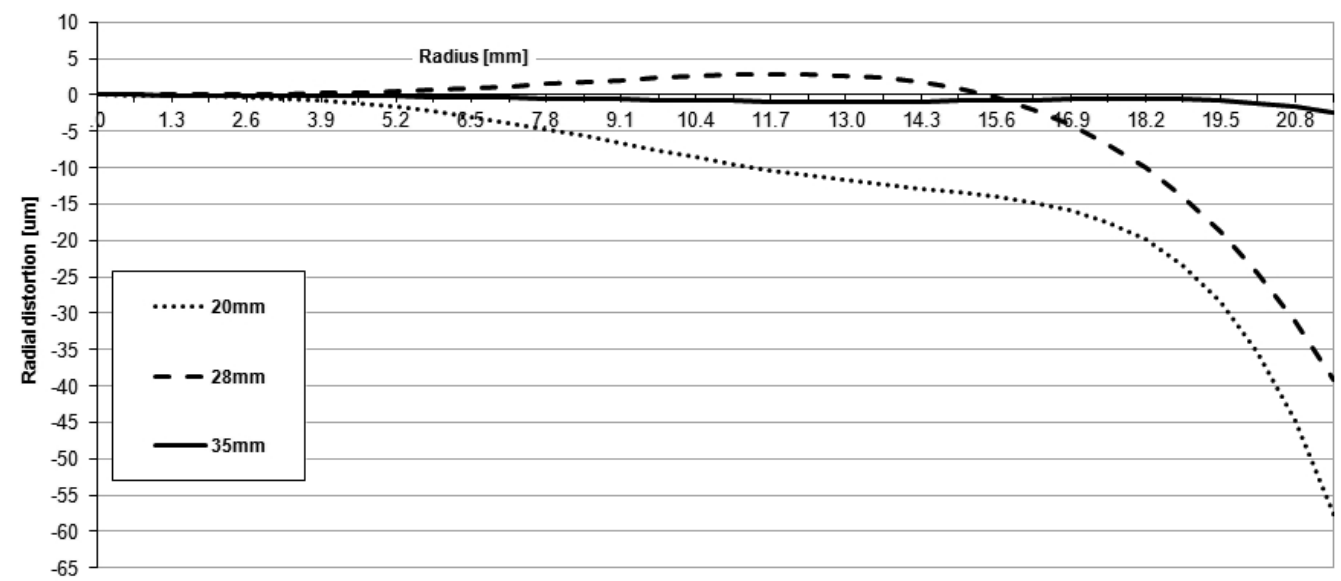

Fig. 2. Radial distortion curves as a result of camera calibration in variant $\# 2$ 
It can be noticed that the ARD works differently for each lens. For $35 \mathrm{~mm}$ the significant reduction of distortion values is observed while for two other lenses, especially for $20 \mathrm{~mm}$ lens the decrease of distortion is not as big. Summarizing results of variants 1 and 2: ARD works in some way and the influence on accuracy of terrain coordinates' measurements has to be evaluated using ChPs.

\subsubsection{Calibration using images with ARD - estimation of IOPs only (variant 3)}

In the third scenario the calibration was calculated using images acquired with ARD. Only the IOPs were estimated. The results are given in the table 4. The RMSE of image coordinates is possible the effect of unreduced distortion and is highest for $20 \mathrm{~mm}$ lens.

Table 4. Results of camera calibration in variant \#3 - estimation of IOPs only

\begin{tabular}{|l|c|c|c|c|c|c|}
\hline \multirow{2}{*}{\multicolumn{1}{|c|}{ Parameter }} & \multicolumn{2}{|c|}{$20 \mathrm{~mm}$ lens } & \multicolumn{2}{c|}{$28 \mathrm{~mm}$ lens } & \multicolumn{2}{c|}{$35 \mathrm{~mm}$ lens } \\
\cline { 2 - 7 } & Value & $\begin{array}{c}\text { Std. } \\
\text { deviation }\end{array}$ & Value & $\begin{array}{c}\text { Std. } \\
\text { deviation }\end{array}$ & Value & $\begin{array}{c}\text { Std. } \\
\text { deviation }\end{array}$ \\
\hline PPAC x [mm] & -0.0494 & 0.0010 & -0.1775 & 0.0011 & -0.0358 & 0.0013 \\
\hline PPAC y [mm] & 0.1808 & 0.0013 & 0.1880 & 0.0014 & 0.2035 & 0.0017 \\
\hline Principal distance $[\mathrm{mm}]$ & 19.8767 & 0.0016 & 28.4117 & 0.0017 & 35.7155 & 0.0028 \\
\hline RMSE [px] & 0.9769 & & 0.7064 & & 0.4167 & \\
\hline
\end{tabular}

\subsection{Summary of results obtained in three calibration scenarios}

The results presented above show that the efficiency of distortion reduction is different for each lens - best for $35 \mathrm{~mm}$ and worst for $20 \mathrm{~mm}$. Table 5 shows the distortion coefficients' ratios. Each proportion was calculated as the division of results in respectively first and second variants.

Table 5. Ratios of distortion coefficients

\begin{tabular}{|c|c|c|c|}
\hline \multirow{2}{*}{ Parameter } & \multicolumn{3}{|c|}{ Focal lenght } \\
\cline { 2 - 4 } & $20 \mathrm{~mm}$ lens & $28 \mathrm{~mm}$ lens & $3 \mathrm{~mm}$ lens \\
\hline$K 1$ & 21.10 & -24.84 & 63.68 \\
\hline$K 2$ & 8.32 & -7.20 & 7.67 \\
\hline$K 3$ & 1.30 & -1.34 & -2.84 \\
\hline$P 1$ & 0.96 & 2.31 & 4.16 \\
\hline$P 2$ & 0.18 & -0.02 & 0.53 \\
\hline
\end{tabular}


This comparison shows that in case of $35 \mathrm{~mm}$ the ARD influences the K1 significantly larger than for other lenses, whereas the influence on other radial coefficients is similar. Looking at $35 \mathrm{~mm}$ ratios a little higher influence at P1 is also observed. It should be mentioned that not only the physics of the lens incorporates $P$ coefficients but also the lens-to-camera mounting.

\section{Control measurements - accuracy analysis}

In order to perform the accuracy analysis two stereo images were captured (Tokarczyk and Boron, 1999). In each variant the exterior orientation parameters were determined via photogrammetric resection using four CPs. Then applying photogrammetric intersection the terrain coordinates of $20 \mathrm{ChPs}$ were calculated and compared with their reference values. The RMSEs determined using calculated differences are provided for each variant of control measurement. Specification of each variant is given in the table 1. Analyzing the results it should be kept in mind that the $\mathrm{Y}$ axis of the test field frame is nearly parallel to the axes of stereo images. It is also sensible to refer obtained RMSEs to the accuracy of spatial resection used for ChPs' coordinates estimation as well as to the accuracies of the reference values. Standard deviations taken from the diagonal of the resection's covariance matrix were averaged over all ChPs and given in the last row of the table. The std. deviations obtained in variant \#1 were used. In this control scenario best accuracies seem to be achieved probably because avoiding influence of calibration inaccuracies resulted from remaining distortion. Errors of reference coordinate values are within $0.04,0.05,0.04 \mathrm{~mm}$ respectively for $X, Y$ and $Z$ coordinates.

Table 6. RMSEs of check points' coordinates

\begin{tabular}{|c|c|c|c|c|c|c|c|c|c|}
\hline \multirow{2}{*}{ Control variant } & \multicolumn{3}{|c|}{$20 \mathrm{~mm}$ lens } & \multicolumn{3}{c|}{$28 \mathrm{~mm}$ lens } & \multicolumn{3}{c|}{$35 \mathrm{~mm}$ lens } \\
\cline { 2 - 11 } & \multicolumn{3}{|c|}{$R M S E[\mathrm{~mm}]$} & \multicolumn{3}{c|}{$R M S E[\mathrm{~mm}]$} & \multicolumn{3}{c|}{$R M S E$ [mm] } \\
\cline { 2 - 11 } & $X$ & $Y$ & $Z$ & $X$ & $Y$ & $Z$ & $X$ & $Y$ & $Z$ \\
\hline 0 & 0.78 & 7.66 & 1.41 & 0.70 & 4.79 & 0.42 & 0.19 & 7.25 & 0.32 \\
\hline 1 & 0.05 & 0.17 & 0.07 & 0.05 & 0.20 & 0.06 & 0.08 & 0.24 & 0.06 \\
\hline 2 & 0.10 & 0.37 & 0.18 & 0.12 & 0.35 & 0.09 & 0.05 & 0.22 & 0.10 \\
\hline 3 & 0.11 & 0.37 & 0.14 & 0.10 & 0.26 & 0.08 & 0.08 & 0.26 & 0.08 \\
\hline $\begin{array}{c}\text { average value of std. dev. } \\
\text { in variant 1 [mm] }\end{array}$ & 0.06 & 0.08 & 0.04 & 0.05 & 0.06 & 0.02 & 0.05 & 0.19 & 0.05 \\
\hline
\end{tabular}




\section{Discussion on results}

Results obtained in three calibration variants as well as altogether four control measurements allow to formulate following concluding remarks:

- In all variants of control measurements highest errors are observed in the Y component - the direction that coincide with the depth direction of the stereo pair. The observed phenomena is typical in photogrammetric measurements.

- The highest RMSEs of ChPs coordinates were achieved in the "zero variant". In this scenario distortion is not taken into account neither using ARD nor standard calibration. Because of high error values this case won't be referred anymore, however it provides the idea how much the accuracy degenerates due to the uncompensated distortion.

- In case of $20 \mathrm{~mm}$ and $28 \mathrm{~mm}$ lenses best results were achieved in variant 1 representing classical calibration. In case of $28 \mathrm{~mm}$ lens this results are only slightly better than for $20 \mathrm{~mm}$ lens.

- In case of $20 \mathrm{~mm}$ and $28 \mathrm{~mm}$ lenses the second variant of control measurement (calibration using images with ARD) brought worse results as the first scenario (in case of $28 \mathrm{~mm}$ lens only slightly worse). It is hard to give reasons of this phenomena. One explanation assumes that ARD takes place according not to the model of Brown and as a result performing the calibration it is impossible to fully reduce the remaining distortion.

- In case of $35 \mathrm{~mm}$ lens, for which ARD seems to work good (Fig. 1), which was confirmed by calibration in variant 1 and 2, results of control measurements in all three scenarios are similar.

- In case of $28 \mathrm{~mm}$ and $35 \mathrm{~mm}$ lens RMSEs of ChPs in variant 3 are similar to values obtained in variants 1 and 2 which may be explained by phenomena mentioned bellow.

- The test-field used for evaluation is located in the flat wall so that possible errors of the network scale arising in its perpendicular direction may not be detected. In such circumstances possibly inaccuracies of IOPs, can be easily compensated during the spatial resection, influencing the values of estimators of external orientation parameters (Pastucha, 2012; Kolecki 2012). In order to avoid this unfavorable phenomena and investigate the network accuracies in all three directions, it would be better to carry out researches in the test field with spatially distributed points.

\section{Final conclusions}

Taking into account results of calibration and control procedure it can be stated that effectiveness of automatic reduction of distortion may be different for each lens model. The best results were achieved for $35 \mathrm{~mm}$ lens. In this case no significant differences between each scenario of control measurement, resulting from different approaches to 
calibration procedure, can be observed. In the case of $28 \mathrm{~mm}$ lens obtained differences were relatively low. However very significant differences were observed for $20 \mathrm{~mm}$ lens. In order to examine the accuracy potential of ARD algorithms, implemented in camera firmware, more deeply it would advantageous to use test field with spatially distributed targets. In case of the on-the-job calibration (Kraus, 1997), the automatic distortion removal can be helpful. Photogrammetric network may not have sufficient number of equally distributed terrain points which is necessary for DMPs estimation (all frame should be equally covered with points). However at the same time geometrical distribution of points and image stations may be sufficient for determining IOPs only. At the same time the zero-valued DMPs may be treated as pseudo observations. On the other hand using images captured with ARD must be carried out with great care because of possible distortion model inconsistency incorporated by camera software: worse results of control measurement in variant 2 with respect to variant 1 can be observed for 20 and $28 \mathrm{~mm}$ lenses (Table 6). To summarize: there is some space to use automatic reduction of distortion in photogrammetry as well as to carry out additional researches using wider spectrum of cameras and lens models and incorporating different focusing distances. However classical calibration stays the best way to treat distortion with the highest accuracy possible.

\section{Acknowledgements}

Researchers was supported by Department of Mining Surveying and Environmental Engineering (AGH University of Science and Technology) under grant no. 11.11.150.949. The tested camera Nikon D800 was available by courtesy of company Terramap sp. zo.o.

\section{References}

Brown, D. (1971). Close range camera calibration. Photogrammetric Engineering, 37(8), 855-866.

Clarke, T. A. and Fryer, J.G. (2003). The development of camera calibration methods and models. http://www. vision.caltech.edu/bouguetj/calib_doc/papers/DevelopmentCameraCalibration MethodsModels.pdf

Grammatikopoulos, L., Karras, G., Petsa, E. and Kalisperakis, I. (2006). A unified approach for automatic camera calibration from vanishing points, Archives of the Photogrammetry, Remote Sensing and Spatial Information Sciences, XXXVI-5, http://www.isprs.org/proceedings/XXXVI/ part5/paper/1261_Dresden06.pdf

Hamid, N.F.H. and Ahmad, A. (2014). Calibration of high resolution digital camera based on different photogrammetric methods. IOP Conf. Series: Earth and Environmental Science 18, (2014) 012030, 6 pages.

Kolecki, J. and Tokarczyk, R. (2007). Automatyczna identyfikacja punktów pola testowego AGH z wykorzystaniem pakietu MATLAB. Archiwum Fotogrametrii, Kartografii i Teledetekcji, 17a, 363-373.

Kolecki, J. (2013). Wyznaczanie elementów orientacji zewnętrznej zdjęć naziemnych z wykorzystaniem obserwacji fotogrametrycznych i inercyjnych oraz satelitarnego systemu pozycjonowani. Wydawnictwa Akademii Górniczo-Hutniczej im. Stanisława Staszica w Krakowie.

Kraus, K. (1997). Photogrammetry vol. 2. Advanced Methods and Applications. Ferd. Duemmlers Verlag, Bonn, 477-453. 
Melo, R., Barreto, J. P. and Falcão, G. (2012). A New Solution for Camera Calibration and Real-Time Image Distortion Correction in Medical Endoscopy - Initial Technical Evaluation. IEEE Transactions on Biomedical Engineering, 59(3), 634-644.

Pastucha, E. (2012). Research on the Influence of the Approximated Principal Distance on the Accuracy of Orthophotoplans Out of Historic Polychrome (on Flat and Quasi-Flat Surface). Geomatics and Environmental Engineering, 6(3), 61-71.

Ricolfe-Viala, C. and Sanchez-Salmeron, A.-J. (2010). Correcting non-linear lens distortion in cameras without using a model. Optics \& Laser Technology, 42, 628-639.

Van der Jeught, S., Buytaert, J. A. N. and Dirckx, J. J. J.(2013). Real-time geometric lens distortion correction using a graphics processing unit. Optical Engineering, 51(2), 5 pages.

Tokarczyk, R. and Boroń, A. (1999). Ocena dokładności rekonstrukcji obiektu z wykorzystaniem aparatu cyfrowego KODAK DC 260. Geodezja, 5(1), 123-133.

Tokarczyk R., and Boroń, A. (2000). Badanie cyfrowych aparatów fotograficznych dla potrzeb fotogrametrii bliskiego zasięgu. Archiwum Fotogrametrii, Kartografii i Teledetekcji, 10(63-2), 63-10.

Tokarczyk, R., Kolecki, J. and Tokarczyk, P. (2007). Wykorzystanie aparatu cyfrowego telefonu komórkowego do wizualizacji 3D kapliczki. Archiwum Fotogrametrii, Kartografii i Teledetekcji, 17b, 769-779.

Wróbel, A., Wróbel, Al. and Kadłubowski, D. (2011). Dystorsja obiektywów kamer termograficznych. Pomiary, Automatyka, Kontrola, 57(10), 1116-1119

\title{
Ocena dokładności automatycznej korekcji dystorsji
}

\author{
Jakub Kolecki, Antoni Rzonca \\ AGH Akademia Górniczo-Hutnicza \\ Wydział Geodezji Górniczej i Inżynierii Środowiska \\ Katedra Geoinformacji, Fotogrametrii i Teledetekcji Środowiska \\ Al. Mickiewicza 30, 30-059 Kraków \\ email: kolecki@agh.edu.pl; arz@agh.edu.pl
}

\section{Streszczenie}

Publikacja ma na celu przedstawienie wyników automatycznego usuwania dystorsji dla niemetrycznej kamery z obiektywem stałoogniskowym. Z punktu widzenia fotogrametrii pojawia się zasadnicze pytanie, czy dokładność określenia dystorsji dla danego typu obiektywu (a nie egzemplarza) jest wystarczająca, żeby otrzymać oczekiwane dokładności pomiaru fotogrametrycznego. W tym celu wykonano dwa rodzaje obliczeń kontrolnych.

Pierwsze obliczenia to kalibracja kamery w wariantach zapewniających szeroką dyskusję wyników, wykonana w oprogramowaniu zapewniającym podanie pełnej analizy dokładności. Dodatkowo każdy wariant został sprawdzony poprzez kalibrację kontrolną, którą policzono na podstawie pomiaru zdjęć z fizycznie usuniętym wpływem dystorsji.

Drugi etap obliczeń - analiza dokładności - polegał na wykonaniu pomiarów sprawdzających punktów kontrolowanych na zdjęciach dla wszystkich 3 zestawów przyjętych lub obliczonych elementów orientacji wewnętrznej oraz dystorsji usuniętej automatycznie lub programem, na podstawie wyników kalibracji.

W publikacji zamieszczono obszerny komentarz dotyczący praktycznych aspektów stosowania każdej z tych metod kalibracji. Wniosek ostateczny podaje zasady stosowania wyników automatycznej redukcji dystorsji w zastosowaniach fotogrametrycznych. 